\title{
REVOLUSI SOSIAL DI SIMALUNGUN TAHUN 1946
}

\author{
Hanif Harahap \\ Program Studi Pendidikan Sejarah, Universitas Samudera, Indonesia \\ Email: suratterdahulu@gmail.com
}

\begin{abstract}
This study aims to determine the factors that triggered a social revolution in Simalungun. Then to find out the process of a social revolution going on, and the impact it has on the social structure of Simalungun. The method used in this study is a historical method that includes 4 stages, namely heuristics, source criticism, interpretation and explanation This research shows the findings; social revolution in Simalungun is a change in social structure with criminal actions based on the sentiments and revenge of certain groups.
\end{abstract}

Keywords: Simalungun, Social Revolution

\begin{abstract}
Abstrak
Penelitian ini bertujuan untuk mengetahui faktor-faktor yang memicu terjadinya revolusi sosial di Simalungun. Kemudian untuk mengetahui proses revolusi sosial terjadi, serta dampak yang ditimbulkan terhadap struktur sosial Simalungun. Metode yang digunakan dalam penelitian ini adalah metode sejarah yang mencakup 4 tahap yaitu heuristik, kritik sumber, interpretasi dan eksplanasi Penelitian ini menunjukkan hasil temuan; revolusi sosial di Simalungun adalah perubahan struktur sosial dengan aksi kriminal yang didasari sentimen dan dendam kelompok tertentu.
\end{abstract}

Kata Kunci: Simalungun, Revolusi Sosial

\section{PENDAHULUAN}

Revolusi sosial merupakan tindakan yang dilakukan rakyat Indonesia dengan menjadikan kaum bangsawan pribumi yang dianggap "kaki tangan" Jepang dan Belanda sebagai musuh (Reid, 1981: 35). Dengan kata lain, revolusi sosial bisa juga disebut sebagai perang saudara sesama bangsa Indonesia.

Banyak hal yang menyebabkan perpecahan antar sesama anak bangsa Indonesia. Mengingat kembali masa pendudukan Jepang, angkatan perang Jepang menciptakan seperang- kat kondisi yang secara luar biasa (penderitaan terhadap rakyat Indonesia) yang memperkuat potensi untuk revolusi Indonesia (Soedjatmoko, 1991: 5).

Setelah proklamasi kemerdekaan Indonesia pada tahun 1945, banyak kerajaan-kerajaan yang memiliki kekuasaan otonom di daerah meragukan kekuatan Republik Indonesia. Mereka (raja-raja) khawatir pemerintah Republik Indonesia tidak cukup kuat untuk mempertahankan kemerdekaannya jika Sekutu dan Belanda datang kembali ke Indonesia. Sikap raja-raja ini 
diartikan oleh para pemuda sebagai sikap keberpihakan raja-raja terhadap Belanda. Hal ini menimbulkan keinginan para pemuda untuk melakukan penurunan secara paksa atau bahkan pembantaian terhadap raja-raja dan bekas pejabat yang bekerja dengan pemerintah kolonial Belanda.

Revolusi sosial terjadi di hampir setiap daerah Indonesia, seperti di Surakarta, Banten, Sukabumi, Aceh dan Sumatera Timur. Begitu juga di Simalungun, revolusi sosial terjadi begitu singkat dengan menelan banyak korban, dan merupakan suatu peristiwa yang berkaitan dengan perkembangan di pusat (Jawa). Oleh karenanya, penelitian ini bertujuan untuk mengetahui faktor-faktor yang memicu terjadinya revolusi sosial di Simalungun. Kemudian untuk mengetahui proses revolusi sosial terjadi, serta dampak yang ditimbulkan terhadap struktur sosial Simalungun.

\section{METODE PENELITIAN}

Metode yang digunakan dalam penelitian ini adalah metode sejarah yang mencakup 4 tahap yaitu heuristik, kritik sumber, interpretasi dan eksplanasi. Ada beberapa dokumen yang menyimpan berbagai informasi tentang revolusi sosial di Indonesia, seperti Algemeen Secretarie en de Daarbij Gedeponeerde Archieven 19421945. Namun, dibandingkan dengan masa sebelum revolusi, dokumen masa revolusi tergolong sangat miskin. Maka dari itu informasi dari beberapa saksi hidup juga digunakan sebagai sumber primer. Dengan demikian, penelitian ini lebih banyak menggunakan sumber lisan.

\section{HASIL DAN PEMBAHASAN \\ Kedatangan Belanda Ke Simalungun}

Kebijakan pemerintah kolonial Belanda menginvasi Simalungun terjadi ketika situasi internal kerjaan-kerajaan di Simalungun mengalami perpecahan. Pada kunjungan yang dilakukan Hijmans van Aanroy (kontrolir Asahan dan Batubara) pada bulan September 1885 melaporkan kepada Residen Hoos di Medan bahwa daerah Simalungun penuh konflik internal (Tideman, 2009: 57).

Pada tahun 1889 pemerintah kolonial Belanda mulai menaklukkan kerajaan-kerajaan Simalungun secara serius. Hal ini tercantum dalam keputusan pemerintah 23 Oktober 1889 Nomor 25 dan 8 Juni 1891 Nomor 21. Kerajaankerajaan yang terlebih dahulu takluk adalah kerajaan Tanah Jawa dan Siantar, kemudian disusul oleh kerajaan-kerajaan Simalungun yang lain.

Belanda menggunakan aura aristokrasi Indonesia tradisional untuk membuat penduduk tunduk dan untuk memperoleh semua konsesi dan tanah yang mereka inginkan dari bonekaboneka itu (Wertheim, 1999: 49).

Kerajaan-kerajaan yang telah menandatangani pernyataan pendek dijadikan Landschap oleh pemerintah kolonial Belanda. Di dalam birokrasi kolonial, landschap adalah pemerintahan Raja-raja yang didampingi oleh aparatur pemerintahan gubernemen, dengan pangkat paling tinggi asisten residen (Suprayitno, 2001: 20). Fungsi dan status para raja tetap dipertahankan, namun kekuasaannya dibatasi. Para raja dibawah kendali dan perintah para pejabat pemerintah kolonial. Dalam pelaksanaan administrasi pemerintahan terdapat dualisme kepemeritahan. Pihak kerajaan memiliki sistem adminstrasi sendiri yang tunduk kepada pemerintah kolonial, sedangkan pemerintah kolonial menugaskan pegawainya mendampingi setiap kerajaan melaksanakan kegiatan pemerintahan tanpa harus tunduk dengan pemerintah kerajaan Simalungun.

Setelah menandatangani pernyataan pendek dengan pemerintah kolonial Belanda, maka kekuasaan para raja Simalungun semakin terbatas. Gelar "raja" hanya sekedar bayangan, sesungguhnya raja dimaksud lebih mirip dengan "kepala adat". Hal ini diperkuat dengan dikeluarkannya surat keputusan pemerintah Belanda Lembaran Negara 1914 No. 24 yang membatasi wewenang raja-raja (Tambak, 1982:129-130). 


\section{Ekspansi Pengusaha Perkebunan}

Undang-Undang Agraria tahun 1870 dalam arti formal menandai berakhirnya sistem Taman Paksa dan beralihnya sistem itu ke zaman liberalisme yang lebih bebas, segera menunjukkan arah politik baru ini: membuka sumber daya alam negeri kepulauan ini bagi kepentingan modal negeri induk (Breman, 1997: 15). Prinsip liberalisme menandai terbukanya Nusantara bagi penanaman modal asing khususnya pengusahapengusaha Eropa dan Amerika.

Meningkatnya kebutuhan akan bahan baku industri di Amerika dan Eropa, secara tidak langsung menjadikan kerajaan tamak. Eksploitasi berbagai sumber daya yang menjanjikan keuntungan merupakan pekerjaan yang dilakukan pada waktu itu (Wertheim, 1999: 49).

Pada waktu tanam-tanaman keras seperti karet, kelapa sawit, sisal, dan teh mulai ditanam di Sumatera Timur, tiga penguasa dari Langkat, Deli dan Serdang dan kepala-kepala daerah kecil di distrik-distrik Batak Karo dan Simalungun bagian pedalaman telah menyerahkan setiap jengkal tanam milik mereka kepada para pengusaha onderneming (Stoler, 1995: 80). Akibatnya rakyat kehilangan tanah yang biasanya bisa mereka manfaatkan untuk menanam padi karena telah menjadi perkebunan.

Kesusahan dan penderitaan rakyat ini segera dilupakan oleh para penguasa pribumi tersebut karena tawaran sejumlah uang sewa tanah yang digunakan untuk perkebunan. Perkembangan perkebunan di Simalungun semakin pesat seiring dengan mudahnya diperoleh tanah dari raja-raja.

\section{Kesenjangan Sosial-Ekonomi}

Kesenjangan sosial-ekonomi antara rakyat Simalungun dengan raja-raja dan bangsawan semakin lebar ketika sistem ekonomi uang dan perkebunan masuk ke Simalungun melalui pemerintah kolonial Belanda. Para raja dan bangsawan menerima lonjakan pendapatan pribadi yang sangat signifikan jauh meninggalkan rakyatnya yang miskin. Raja-raja Simalungun menerima gaji sebesar f. 6.720 per tahun, dua raja yang terkaya juga menikmati tunjangan bepergian sebesar f. 1.800 per tahun dan sejumlah besar upeti tradisional dari rakyatnya (Reid, 2012: 79). Raja-raja Simalungun juga menerima keuntungan yang besar dari perkebunan itu (Suprayitno, 2001: 22).

Sejalan dengan kekayaan yang luar biasa ini muncul perubahan gaya hidup sebagian raja dan bangsawan Simalungun. Setelah hadirnya sistem ekonomi perkebunan mereka telah mampu membangun istana-istana megah, membeli mobil mewah, dan pesiar ke Eropa. Gaya hidup mewah pada gilirannya mewarnai kehidupan mereka sehari-hari (Reid, 2012: 22). Berbeda halnya dengan rakyat yang semakin "terjepit".

\section{Rakyat Simalungun di bawah Mobilisasi Jepang}

Pasukan Jepang memberi suntikan propaganda anti-Barat dalam dosis lama kepada rakyat, yang membuat rakyat selama pendudukan Jepang membenci Belanda (Kahin, 1995: 227). Tak terlewatkan propaganda juga dilakukan pasukan Jepang kepada rakyat Simalungun untuk membenci kaki-tangan Belanda dan segala sesuatu yang terkait dengan Belanda dan Sekutu.

Rakyat diperintah untuk melakukan kerja paksa, menyetor bahan makanan dan pakaian serta harta benda kepada pasukan Jepang. Terbatasnya jumlah pasukan Jepang dalam perang Asia Timur Raya memaksa mereka mengambil kebijakan untuk menggunakan pemudapemuda Nusantara untuk melapis pasukan inti Jepang (Reid, 1986: 187).

Dari pendudukan Jepang muncul satu kekuatan andalan yang revolusioner, yaitu pemuda. Pemerintah militer mendapat keabsahan. Mobilitas masyarakat maju pesat (Langenberg, 1990: 125). Para pemuda tergabung dalam kesatuan-kesatuan pasukan cadangan Jepang seperti Kenko Kutai, Gyugun, Heiho dan lainnya. Laskar-laskar ini memiliki andil yang cukup besar nantinya pada masa revolusi hingga tahun 1949. 


\section{Raja dan Bangsawan Bekerjasama dengan Jepang}

Tentara pendudukan Jepang memasuki daerah Simalungun melalui Tanjung Balai dan Pantai Cermin pada bulan Februari 1942. Kedudukan raja-raja nampaknya tidak diganggu gugat pihak Jepang (Purba, 1987: 51). Kekuasaan raja-raja dijamin oleh Jepang, namun penghasilan raja "digencet" terus. Hasil tanahnya dicabut (Merdeka, 15 Maret 1946). Mereka (raja-raja) mengabdi kepada Jepang seperti mengabdi kepada Belanda dulu (Kahin, 1995: 225).

Raja-raja Simalungun tidak bisa berbuat apa-apa selain menuruti segala perintah dari pasukan Jepang. Namun perintah-perintah pasukan Jepang tersebut dirasa sangat memberatkan rakyat. Kebijakan politik Jepang ini memperlebar jurang perbedaan antara rakyat dan para pemimpinnya, dan menimbulkan rasa dendam yang meledak sejak Agustus 1945 (Lucas, 1989: 37). Rakyat sudah bermaksud akan mengambil tindakan. Namun batal karena rupanya Jepang juga menganut imperialisme yang serupa saja dengan Belanda (Merdeka, 15 Maret 1946).

Kewajiban paksa menyetorkan padi kepada penguasa Jepang merupakan kewajiban terberat bagi mayoritas di antara sekian banyak kebijaksanaan politik Jepang di masa perang itu (Lucas, 1989: 41). Hal ini disebabkan lahan pertanian di Simalungun yang sedikit karena telah digunakan menjadi perkebunan. Akhirnya banyak rakyat Simalungun mengalami kelaparan, bahkan tidak sedikit yang mati kelaparan.

Situasi semakin bergolak ketika pasukan Jepang melakukan tindakan ketidakadilan secara nyata terhadap rakyat. Pemerintahan Jepang mengutamakan distribusi beras antara lain untuk kepentingan "semi militer" yaitu pendukungpendukung pentingnya antara lain pengawai pangreh praja. Sebagian besar elite yang mendukung Jepang dan dianggap penting. Sedangkan pribumi dianggap golongan yang tidak berarti (Lucas, 1989: 41).

Hal ini jelas menyebabkan timbulnya kebencian dan dendam "rakyat" terhadap para raja.
"Rakyat" menunggu dan berharap suatu saat nanti dapat membalaskan penderitaan, kesulitan dan sakit hati mereka kepada para raja dan bangsawan. Pendudukan Jepang menciptakan seperangkat kondisi yang secara luar biasa memperkuat potensi untuk revolusi (Soedjatmoko, 1991: 5).

\section{Aktor Intelektual, Massa dan Kelembagaan dalam Revolusi Sosial}

1. Aktor Intelektual

Aktor intelektual revolusi sosial di Simalungun dapat dikategorikan ke dalam tiga kelompok, berdasarkan orientasi ideologi, mobilitas sosial, senioritas dan campuran beberapa kelas sosial. Pertama, ialah kelompok tokoh-tokoh yang turut andil dalam pergerakan nasional. Tokoh-tokoh ini turut berperan penting pada masa setelah kemerdekaan dengan memobilisasi massa dalam berbagai gerakan mempertahankan kemerdekaan. Tokoh-tokoh ini, seperti Marzuki Lubis dan Saleh Umar dari Gerindo-Partindo-PNI, Natar Zainuddin, Abdul Xarim M.S. dari PKI dan lain-lain.

Kedua, ialah kelompok pemuda nasionalis yang mengalami mobilitas sosial akibat pernah mendapat pendidikan militer oleh pasukan Jepang. Namun sebagian tokoh juga telah terlebih dahulu berkecimpung di dunia politik sebelum pendudukan Jepang, seperti Yakub Siregar yang pernah menjadi anggota Gerindo pada tahun 1930-an pada masa pergerakan nasional. Banyak mantan prajurit Gyugun ditarik menjadi Tentara Republik Indonesia, seperti Ahmad Tahir. Yakub Siregar terlibat dalam pembentukan atau pelatihan kesatuan-kesatuan laskar rakyat seperti BHL (Barisan Harimau Liar) pada sekitar awal tahun 1945.

Ketiga, ialah kelompok pemuda yang relatif tidak berpengaruh, namun menjadi sangat penting ketika mereka menjadi pelaksana lapangan revolusi sosial. Pada setiap misi (revolusi sosial) yang mereka kerjakan, mereka selalu menjadi pemimpin yang disegani anggotanya bagi laskar yang mereka pimpin. Banyak 
yang aktif di unit-unit militer atau organisasi pemuda semasa pendudukan Jepang. Mereka antara lain, para pemimpin laskar seperti Bejo, Timur Pane, Payung Bangun, Saragih Ras, Nip Xarim, Sarwono S. Sutarjo dan Liberty Malau (Langenberg, 1990: 127).

\section{Partai Politik dan Laskar Rakyat}

Maklumat No. X yang dikeluarkan pemerintahan Hatta pada 3 November 1945 tentang kebebasan membentuk partai-partai politik di seluruh wilayah republik telah menimbulkan dampak yang luar biasa. Salah satunya adalah para pemuda yang selama masa perjuangan bertindak secara tidak terkomando kini memiliki lembaga tempat bernaung.

Laskar-laskar rakyat tersebut merupakan kesatuan-kesatuan bersenjata yang berdiri sendiri di bawah organisasi-oraganisasi politik, misalnya Laskar Merah dari PKI, Napindo (Nasional Pelopor Indonesia) dari PNI, Hisbullah dari Masyumi, Laskar Buruh dari Partai Buruh Indonesia, Barisan Parkindo, Barisan Mujahidin dari PUSA, Syarikat Nelayan Indonesia, Barisan Harimau Liar, Kesatria Pesindo dari Pesindo. Diantara laskar ini maka Pesindo dan Napindo adalah yang terkuat, begitu pula Hisbullah dan Mujahidin adalah pasukanpasukan laskar-laskar yang termasuk kuat juga (Proyek Penelitian dan Pencatatan Kebudayaan Daerah, 1978: 138).

Republik Indonesia baru memulai hidupnya tanpa tentara pemerintah berjuang keras mengandalikan banyaknya kelompok bersenjata yang telah muncul pada hari-hari pertama revolusi (Gonggong, 2011: 67). Kelompok bersenjata tersebut terlahir dari kesatuankesatuan komunal lokal beradasarkan suatu ikatan yang kuat, baik itu suku, agama atau bahkan pengalaman di masa penduduk Jepang (pernah dilatih dalam kesatuan pasukan propaganda Jepang).

Sejak bulan Desember "Markas Agung" dari Sarwono berusaha mengkoordinir laskarlaskar yang terkotak-kotak ini dan membicara- kan persoalan swapraja dengan penasehatnya, Nathar Zainuddin dan Abdul Xarim M. S. Pada waktu itu mereka telah mempunyai suatu rencana rahasia untuk menghapuskan sama sekaliswapraja di Sumatera Timur (Forum Komunikasi Ex Sub Teritorium VII Komando Sumatera, 1979: 143). Namun karena ketidakpercayaan beberapa organisasi dan laskar kepada Markas Agung menjadikan Markas Agung vakum. Selain itu, Moh. Hasan selaku pemimpin tertinggi Sumatera juga tidak setuju dengan rencana Markas Agung tersebut.

Laskar-laskar tersebut baru bisa disatukan oleh Persatuan Perjuangan. Hal ini disebabkan Persatuan Perjuangan memiliki agenda yang sangat jelas, merdeka $100 \%$ dan mengubah Daulat Tuanku menjadi Daulat Rakyat.

\section{Realisasi Revolusi}

Di Siantar (bagian dari Simalungun) sloganslogan yang dicoretkan di tembok-tembok rumah seperti "raja-raja penghisap darah rakyat" dan "rakyat menjadi hakim". Pekik "merdeka" dengan kepalan tangan diacungkan ke atas berbaur dengan pekik "darah" yang memuntut pembalasan terhadap raja-raja (Reid, 2012: 315).

Pasukan dari laskar-laskar Pesindo dan Napindo (PNI) ditugaskan membunuh raja Siantar (NEFIS 14 Maret 1946, Inv. Nr. 26626). Pada saat pasukan Pesindo dan Napindo merangsek masuk ke istana kerajaan Simalungun untuk membunuh pemangku raja Tuan Sawadim Damanik, mereka (Pesindo dan Napindo) tidak mendapati Tuan Sawadim Damanik di istana. Beliau sedang berada di kediaman orangtuanya di Pematang Bandar. Pasukan tersebut tidak menyerah, mereka mengejar Tuan Sawadim ke Pematang Bandar dan berniat membunuhnya disana. Pembunuhan mengalami kegagalan karena para pendatang Toba yang telah cukup lama tinggal di Bandar dalam membuka lahan persawahan melindungi Tuan Sawadim Damanik. Para pendatang Toba tersebut dengan setia berani menghalau pasukan Pesindo dan Napindo 
dalam menjalankan misinya (Wawancara E. L. Damanik, Januari 2013).

Di Raya pemangku raja Raya Tuan Jan Kaduk Saragih Garingging menjadi korban kekejaman pasukan Barisan Harimau Liar (BHL). Pada tanggal 4 Maret 1946 pasukan BHL berhasil masuk ke istana raja Raya dan memporakporandakan seisinya. Harta benda seperti emas dan barang-barang berharga diambil. Beliau beserta keluarganya dibawa menuju satu jembatan besar Bah Hutailing, kepalanya dipotong dan selanjutnya mayatnya dihanyutkan ke sungai yang berada di bawah jembatan (Wawancara J. Saragih, Januari 2013).

Informasi revolusi sosial telah terdengar oleh pihak kerajaan Panei sebelum revolusi itu dilaksanakan. Ialah Tuan Mailan Purba Dasuha yang mendapatkan informasi itu dan langsung memberi tahukannya kepada raja Panei Tuan Bosar Sumalam Purba Dasuha. Selain itu, raja Panei juga menerima informasi tentang revolusi sosial tersebut dari Tuan Nagapanei, yang menyebutkan bahwa pasukan yang akan merevolusi kerajaan Panei adalah BHL yang dipimpin oleh A.E. Saragih Ras yang merupakan keluarga dekat raja Panei sendiri (Wawancara Nasir Purba, Januari 2013).

Raja Panei beranggapan bahwa BHL tidak akan mungkin membunuhnya karena pasukan tersebut dipimpin oleh keluarga dekatnya, yaitu A.E. Saragih Ras. Namun suatu peristiwa yang tak terduga terjadi, pasukan BHL melakukan penikaman, penembakan secara tiba-tiba terhadap pasukan kerajaan Panei. Teriakan-teriakan kesakitan prajurit kerajaan Panei menambah ketakutan prajurit-prajurit kerajaan Panei yang lain. Pasukan kerajaan Panei seketika berhamburan ketakutan, bagi mereka yang tertangkap langsung dibunuh di tempat (Wawancara Nasir Purba, Januari 2013).

Raja Panei Tuan Bosar Sumalam dan beberapa bangsawan lainnya, seperti Tuan Marga Bulan Purba Dasuha, Tuan Djautih dan keluarga kerajaan serta rakyat Panei yang menjaga istana ditangkap, diikat kemudian dimasukkan ke dalam truk (NEFIS 14 Maret 1946, Inv. Nr. 26626). Mereka semuanya disiksa secara sadis (lidahnya dicabut secara paksa). Sebelum melakukan pembunuhan, mereka (BHL) melakukan ritual upacara khusus di Nagori. Raja Panei dibunuh dengan cara dipenggal kepalanya, dengan tombak menembus duburnya hingga ke leher (Dasuha, 2010: 9).

TRI melakukan pengejaran terhadap pasukan BHL hingga ke Saribu Dolok dan Tiga Ras. Disana TRI mendapati jasat raja dan bangsawan Panei dengan kondisi yang memprihatinkan. Pengejaran terhadap BHL terhenti karena terpecahnya perhatian TRI dalam Agresi Militer Belanda. Hal ini menyebabkan BHL masih bebas berkeliaran hingga tahun 1947 (Wawancara Nasir Purba, Januari 2013).

Bagus Saragih seorang pemimpin PKI ditugaskan Persatuan Perjuangan untuk melaksanakan misi pembantaian raja kerajaan Tanah Jawa. Dalam misi tersebut Tuan Mintahain Sinaga dari Partuanon Dolok Panribuan beserta anaknya Tuan Hormajawa Sinaga ditangkap pasukan Laskar Merah, disiksa lalu dibunuh. Pasukan Laskar Merah melakukan tindakantindakan yang tidak manusiawi dengan mencincang-cincang jasat kedua bangsawan tersebut, mencampurnya dengan daging kerbau untuk seterusnya disantap beramai-ramai oleh pasukan Laskar Merah (Wawancara Reimon Silaban, Januari 2013).

Raja Purba Tuan Mogang Purba berhasil menyelamatkan diri dari serangan pasukan BHL dan Pesindo. Beliau memutuskan untuk lari ke Pematangsiantar dan meminta perlindungan TRI. Raja Purba diselamatkan oleh TRI sebelum kedatangan pasukan BHL dan Pesindo (NEFIS 14 Maret 1946, Inv. Nr. 26626). Namun ternyata pasukan BHL dan Pesindo tetap memburu raja Purba hingga tahun 1947 bertepatan dengan agresi yang dilakukan Belanda. Dalam percobaan pembunuhan kedua kalinya ini beliau dibunuh bersama putranya (Wawancara E. L. Damanik, Januari 2013). 
Pasukan BHL mencoba merangsek masuk ke daerah kerajaan Dolok Silau pada sekitar tanggal 4 Maret 1946. Salah seorang bangsawan kerajaan Dolok Silau yang bernama Abdul Rahman Purba Tambak mencegahnya aksi pembunuhan yang akan dilakukan pasukan BHL kepada raja Dolok Silau Tuan Bandar Alam Purba Tambak. Keberhasilan beliau menghadang aksi pembunuhan tersebut tidak terlepas dari profesi dan jasanya yang juga seorang komandan laskar rakyat yang tergabung dalam Napindo. Beliau memiliki pasukan khusus yang setia dan siap sedia bertempur jika diperintahkannya. Saat menghadapi pasukan BHL Abdul Rahman Purba Tambak berkata "saya bangsawan kerajaan Dolok Silau, saya juga prajurit republik. Jika kalian (BHL) ingin membunuh raja Dolok Silau, maka kalian harus membunuh saya terlebih dahulu". Musuh sejati dari gerakan revolusi adalah sekutu dan Belanda, bukan rajaraja. Jika ingin melakukan revolusi sosial, maka hak kekuasaan, struktur sosial kerajaan dan kepemilikan alat produksilah yang direvolusi, bukan penghilangan nyawa. Perang saudara diantara raja-raja dengan rakyat merugikan bangsa Indonesia, karena melemahkan kekuatan revolusi melawan Sekutu dan Belanda (Wawancara Abdul Rahman Purba Tambak, Februari 2013).

Raja Silimakuta kebetulan berada di Siantar ketika rumahnya disergap dan kemudian dibakar. Bersama dengan raja-raja Simalungun lainnya, mendapatkan pengamanan dalam tahanan TRI di Pematangsiantar (Reid, 2012: 318). Masih terdapat kesimpang-siuran informasi mengenai raja Silimakuta yang didapat dari beberapa sumber, sebagian menyebutkan raja Silimakuta Tuan Padiaraja Purba Girsang dibunuh pasukan BHL saat mencoba melarikan diri ke Tanah Karo. Setelah dibunuh jasatnya dibuang ke sungai Lau Dah dekat Kabanjahe. Sumber lain menyebutkan bahwa beliau tidak dibunuh pasukan BHL karena beliau merupakan anggota Markas Agung. Selain itu beliau juga terlibat dalam pelatihan militer para pemuda pada masa pedudukan Jepang (Wawancara Abdul Rahman Purba Tambak, Februari 2013).

\section{SIMPULAN}

Revolusi sosial yang terjadi di Simalungun, muncul tidak hanya karena satu faktor penyebab, tetapi sangat kompleks. Penyebab paling kuat menyulut revolusi adalah isu Comite van ontvangst yang membuat rakyat menganggap raja-raja kaki-tangan Belanda.

Masuknya sistem kapitalisme perkebunan telah membuat kesenjangan sosial sosialekonomi di Simalungun antara rakyat dengan raja. Semakin menyulut kebencian rakyat dengan raja.

Masa pendudukan Jepang adalah masa tersulit dan menyakitkan bagi rakyat Indonesia. Keadaan sulit tersebut semakin memperbesar peluang terjadinya revolusi. Pada masa pendudukan Jepang, mereka (Jepang) memberi suntikan propaganda anti-Barat dalam dosis lama kepada rakyat, yang membuat rakyat selama pendudukan Jepang membenci Belanda dan kaki-tangannya. Selain itu para pemuda mendapat pelatihan kemiliteran oleh pasukan Jepang untuk membantu Jepang dalam perang Asia Timur Raya. Kesatuan-kesatuan inilah kelak menjadi laskar-laskar rakyat yang sebagian besar meneror dan melakukan pembunuhan terhadap raja-raja.

Dikeluarkannya maklumat No. X oleh pemerintah semakin menambah eksistensi laskarlaskar rakyat yang sempat dibubarkan pasca kekalahan Jepang dengan Sekutu. Laskar-laskar tersebut langsung dimobilisasi oleh tokoh-tokoh pemuda berhaluan "kiri" seperti Xarim M.S., Nathar Zainuddin, Saleh Umar, Jakub Siregar dan Junus Nasution untuk gerakan-gerakan revolusi, termasuk revolusi sosial.

\section{REFERENSI}

Breman, J. (1997). Menjinakkan Sang Kuli; Politik Kolonial, Tuan Kebun dan Kuli di Sumatra Timur pada Awal Abad ke-20. 
Jakarta: PT. Pusataka Utama Grafis.

Dasuha, J. R. P. (2010). Revolusi Sosial Berdarah di Simalungun Tahun 1946-1947. In Harungguan Bolon, DPP Presidium Partuha Maujana Simalungun. Pematangsiantar.

Forum Komunikasi Ex Sub Teritorium VII Komando Sumatera. (1979). Perjuangan Rakyat Semesta Sumatera Utara. Jakarta: Forum Komunikasi Ex Sub Teritorium VII Komando Sumatera.

Gonggong, A. (2011). Pemuda dan Gerakan Bersenjata: Indonesia Masa Pendudukan Jepang. Prisma, 30, 55-71.

Kahin, G. M. T. (1995). Nasionalisme dan Revolusi di Indonesia. Solo: Sebelas Maret University Press.

Langenberg, M. V. (1990). Sumatera Timur: Mewadahi Bangsa Indonesia dalam sebuah Keresidenan di Sumatera. In A. R. Kahin (Ed.), Pergolakan Daerah pada Awal Kemerdekaan (pp. 119-1948). Jakarta: PT. Pustaka Utama Grafiti.

Lucas, A. E. (1989). Peristiwa Tiga Daerah: Revolusi dalam Revolusi. Jakarta: PT. Pustaka.

Merdeka, 15 Maret 1946.

Proyek Penelitian dan Pencatatan Kebudayaan Daerah. (1978). Sejarah Daerah Sumatera Utara. Jakarta: Departemen Pendidikan dan Kebudayaan, Proyek Penerbitan Buku Bacaan dan Sastra Indonesia dan Daerah.

Purba, D. K. (1987). Sejarah Simalungun. Pematangsiantar: Tanpa penerbit.

Reid, A. (1981). Revolusi Sosial: Revolusi Nasional. Prisma, 8, 33-40.

Reid, A. (1986). The Revolution in Regional Perspective. In J. V. Goor (Ed.), The Indonesian Revolution: Conference Papers. Utrech: Rijk Universiteit Utrech.

Reid, A. (2012). Sumatera: Revolusi dan Elite Tradisional. Jakarta: Komunitas Bambu.
Soedjatmoko. (1991). Pilihan dan Peluang: Revolusi Indonesia Setelah 45 Tahun, Beberapa Refleksi Pribadi. Jurnal Sejarah, 1, 1-16.

Stoler, A. L. (2005). Kapitalisme dan Konfrontasi di Sabuk Perkebunan Sumatra, 1870-1979. Yogyakarta: Karsa.

Suprayitno. (2001). Mencoba (Lagi) Menjadi Indonesia. Yogyakarta: Yayasan untuk Indonesia.

Tambak, T. B. A. P. (1982). Sejarah Simalungun. Pematangsiantar: Tanpa penerbit.

Netherlands Forces Intelligence Service (NEFIS) 14 Maret 1946, Inv. Nr. 26626, Alg. Secre., No. 180, ANRI.

Tideman, J. (2009). Simalungun: Tanah Batak Timur dalam Keterasingan dan Perkembangannya Menjadi Bagian Daerah Perkebunan Pantai Timur Sumatra. Jakarta: Tanpa penerbit.

Wawancara Abdul Rahman Purba Tambak, Februari 2013.

Wawancara E. L. Damanik, Januari 2013.

Wawancara J. Saragih, Januari 2013.

Wawancara Nasir Purba, Januari 2013.

Wawancara Reimon Silaban. (2013). No Title.

Wertheim, W. F. (1999). Masyarakat Indonesia dalam Transisi: Studi Perubahan Sosial. Yogyakarta: PT. Tiara Wacana. 